\title{
The results of numerical simulation of the work of the geotechnical screen of a sparse row of piles
}

\author{
Vladimir Znamenskiy* and Evgenii Morozov \\ Moscow State University of Civil Engineering, Yaroslavskoe shosse, 26, Moscow, 129337, Russia
}

\begin{abstract}
This article is devoted to a computational investigation of the work and the effectiveness of using a geotechnical screen from a sparse row of piles to reduce the yield of the building foundation of surrounding buildings caused by the installation of a reinforced concrete "diaphragm wall", which serves as a barrier for a deep excavation, opened for the construction of a new building erected in constrained urban conditions. As a result of studies carried out using the MIDAS GTS NX software package, it was shown that the curtain grouting depends on the parameters of its design, which include the axial distance between piles, their diameter and length, and the location between the trench under the "diaphragm wall" "And the protected building, reduces the precipitation of buildings surrounding the buildings, caused by digging up the trench, by $50-60 \%$. Analysis of the obtained data allowed us to establish the most significant parameters affecting the efficiency of geotechnical use on the screen of the rarefied number of stilts, define the limits of the maximum efficiency of its use and give practical recommendations for its design.
\end{abstract}

\section{Introduction}

During the construction of buildings and structures in conditions of constrained urban development, the device of deep excavation is made under the protection of building envelope. In many cases, a monolithic "diaphragm wall" of a trench type is used as a fence of the excavation; moreover, as practice and performed geotechnical calculations show, a significant proportion of sediment near buildings occurs at the stage of its construction. So, according [1], precipitation of buildings of the surrounding buildings, caused by the construction of a trench-type "diaphragm wall", can reach up to $80 \%$ of the total precipitation caused by new construction. In recent years, geotechnical screens of various designs, arranged between the fence of the excavation and the protected building, are often used to reduce these deposits. One of the variants of such a geotechnical screen may be a construction of a sparse row of piles, which has long been successfully used for mounting dip-slopes and bluffs, as well as in fencing excavation. The purpose of the numerical calculations, the results of which are presented in this article, was to establish the dependence of the efficiency of its use on a number of factors, including the parameters of

\footnotetext{
* Corresponding author: geosts@yandex.ru
} 
its design and location between the "diaphragm wall" trench and the building to be protected.

\section{Methods}

Mathematic simulation of the interprocess communication of the protective shield piles with the surrounding soil massif was carried out by the finite element method in spatial formulation using the MIDAS GTS NX software package.

Solid-body elements (Solid Elements) of pyramidal or prismatic shape were used to simulate volumetric solids (Fig. 1).
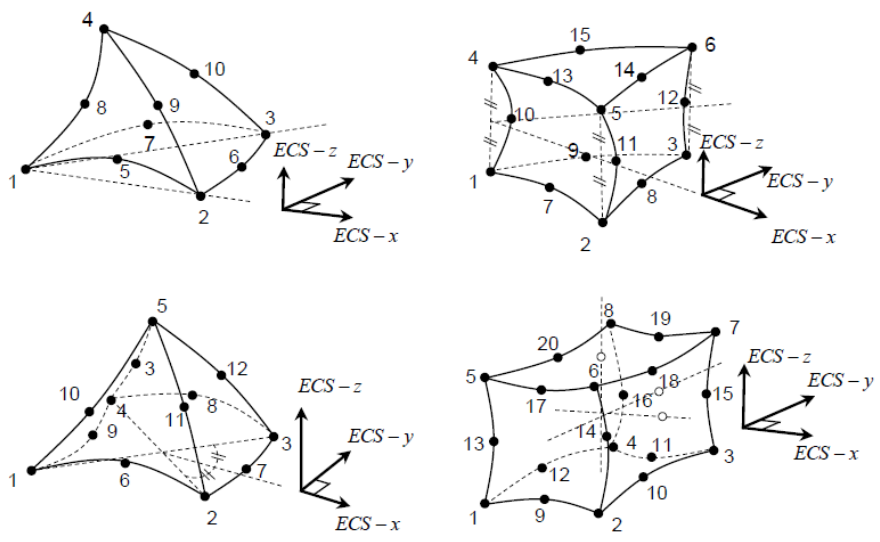

Fig. 1. Volumetric solid elements

To take into account for the interaction of soil with pile structures, flat contact member (Contact Member) were used (triangular (6 knots, 13 knots) or rectangular in shape (8 knots, 16 knots) (Fig. 2).
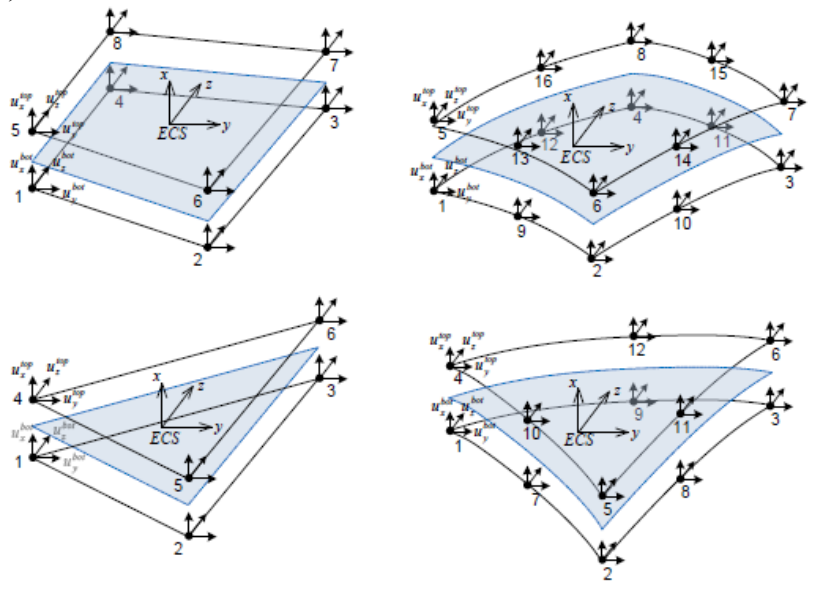

Fig. 2. Flat contact members

While modeling the design scheme, restrictions were imposed on displacements in the horizontal direction (along the $\mathrm{X}$ and $\mathrm{Y}$ axes) on the side vertical edges of the computational domain, as well as a ban on movements in all directions on its lower horizontal face. 
The behavior of the soil mass was modeled using the elastoplastic modified MohrCoulomb model (Modified Mohr - Coulomb).

Studies were conducted for the screen in sandy and clay soils.

The values of the physical and mechanical characteristics of the soils used in the calculation are given in Table 1.

Table 1. The values of the physical and mechanical characteristics of the soils

\begin{tabular}{|l|c|c|c|}
\hline \multicolumn{1}{|c|}{ Soil characteristics } & $\begin{array}{c}\text { Reference } \\
\text { designation }\end{array}$ & $\begin{array}{c}\text { Unit } \\
\text { measure }\end{array}$ & Amount \\
\hline Sand & $E$ & $\mathrm{MPa}$ & 20 \\
\hline Modulus of deformation & $E_{u r}$ & $\mathrm{MPa}$ & 60 \\
\hline Unloading-reloading modulus & $v$ & - & 0,3 \\
\hline Poisson's ratio & $c$ & $\mathrm{kPa}$ & 0,0 \\
\hline Specific cohesion & $\phi$ & ${ }^{-}$ & 30 \\
\hline Angle of internal friction & $\gamma$ & $\mathrm{kN} / \mathrm{m}^{3}$ & 18 \\
\hline Volume weight & \multicolumn{3}{|l|}{} \\
\hline Loam & $E$ & $\mathrm{MPa}$ & 20 \\
\hline Modulus of deformation & $E_{u r}$ & $\mathrm{MPa}$ & 60 \\
\hline Unloading-reloading modulus & $v$ & - & 0,35 \\
\hline Poisson's ratio & $c$ & $\mathrm{kPa}$ & 20,0 \\
\hline Specific cohesion & $\phi$ & ${ }^{\circ}$ & 18 \\
\hline Angle of internal friction & $\gamma$ & $\mathrm{kN} / \mathrm{m}^{3}$ & 18,0 \\
\hline Volume weight & \multicolumn{4}{|l}{} \\
\hline
\end{tabular}

For operation simulation of the work of the foundations and piles of the screen, a linearelastic model with stiffness characteristics is used, are given in Table 2.

Table 2. The values of the physical and mechanical characteristics of the materials

\begin{tabular}{|l|c|c|c|}
\hline \multicolumn{1}{|c|}{ Materials characteristics } & $\begin{array}{c}\text { Reference } \\
\text { designation }\end{array}$ & $\begin{array}{c}\text { Unit } \\
\text { measure }\end{array}$ & Amount \\
\hline Reinforced concrete & $E$ & $\mathrm{MPa}$ & 29000 \\
\hline Elasticity modulus & $v$ & - & 0,3 \\
\hline Poisson's ratio & $\gamma$ & $\mathrm{kN} / \mathrm{m}^{3}$ & 24,0 \\
\hline Volume weight &
\end{tabular}

The effectiveness of a protective screen from a sparse row of piles was determined by comparing the results of the calculation of the settlement analysis located at some fixed distance from the trench of the "diaphragm wall", with or without a protective screen. In the calculations, the screen parameters (diameter of piles, screen depth, axial distance between piles), the screen distance from the "diaphragm wall" trench, the depth of the trench and the distance from the building to the trench were changed.

At the first stage, the calculation of the settlement analysis during the development of a trench under the "diaphragm wall" without the use of a protective screen was carried out. The design scheme for the problem of the development of a trench on additional sediments of a nearby building and its finite element model are shown in Fig. 3. The computational domain included a massif of soil and the foundation of the building. The body weight of the base soil and reinforced concrete foundation was set as the bulk forces. The design situation was simulated in stages. At the first stage, the initial natural stress-strain state of the soil massif was created. At the second stage, an operational load $\mathrm{P}=200 \mathrm{kPa}$ was applied to the foundation. Further, the development of a trench was simulated, while the presence of a 
bentonite solution was taken into account by increasing with depth the pressure on the walls and bottom of the trench. The specific gravity of the clay mortar was taken equal to and $\rho b$ $=11 \mathrm{kN} / \mathrm{m}^{3}$.

a)

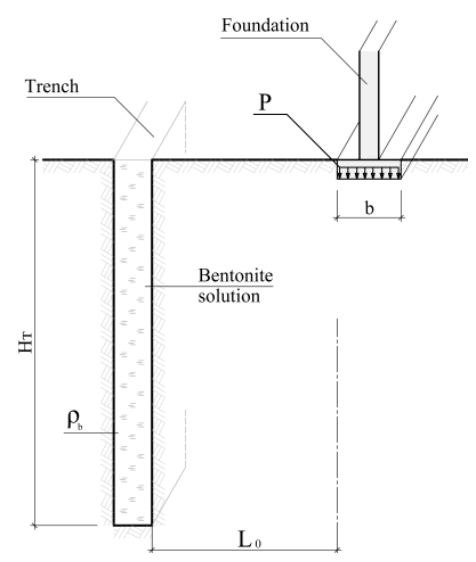

b)

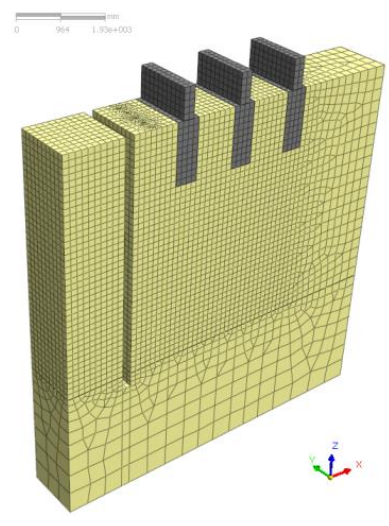

Fig. 3 Development of a trench without a protective screen: $\mathrm{a}$ - design scheme; $\mathrm{b}$ - finite element model

The calculation showed that the values of additional sediment $\mathrm{S}(\mathrm{mm})$ caused by the development of a trench without the use of a protective screen, depending on soil conditions, as well as the depth of the trench and its distance from the building foundation are in the range $\mathrm{S}=25-40 \mathrm{~mm}$, which, depending on the category technical condition of the building, may exceed the limiting values of additional settlement of buildings surrounding the building, regulated by the norms of the Russian Federation.

An example of vertical isopoles (along the $\mathrm{Z}$ axis) and horizontal (along the $\mathrm{X}$ axis) deformations of the soil mass when developing a trench without using a protective screen are shown in Fig. 4.

a)

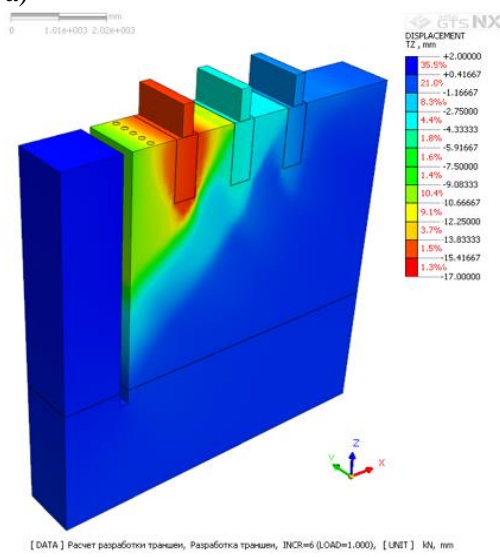

b)

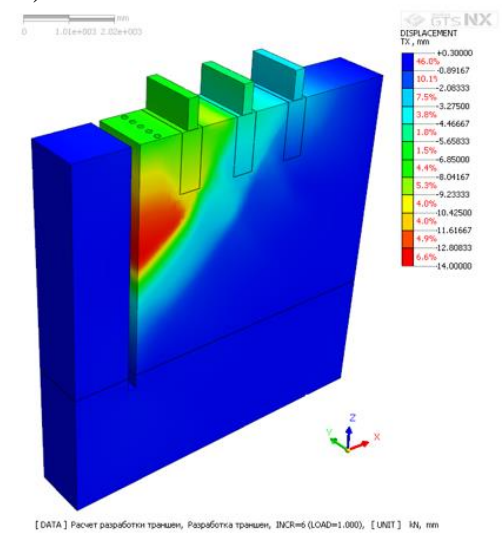

Fig. 4. The results of the calculation in the development of the trench without the use of cutoff screen:

$\mathrm{a}$ - strain along the $\mathrm{Z}$ axis; $\mathrm{b}$ - strain along the $\mathrm{X}$ axis

At the next stage of the simulation, calculations of the building settlement were carried out when developing a trench under the "diaphragm wall" using a protective screen. The 
dimensions of the computational domain, the depth of the trench and its location relative to the foundation were taken to be similar to the previous calculation. The calculation was also carried out in stages. At the first stage, the initial natural stress-strain state of the soil massif was created. At the second stage, an operational load was applied to the foundation. At the third stage, the piles of the geotechnical screen were arranged, and the device filled with a bentonite solution was intermediately simulated. At the final stage, trench development was modeled. The results of each simulation stage were the initial conditions for the next simulation stage.

The design diagram of the "diaphragm wall" device in the immediate vicinity of the existing building in the presence of a geotechnical protective screen from a sparse row of piles is shown in Fig. 5

The protective screen was simulated with changing parameters of its design and location, which included the geotechnical screen $\mathrm{H}_{\mathrm{S}}$ depth, pile diameter $\mathrm{d}$, pitch-diameter ratio a/d, relative distance from screen to $\mathrm{L}_{\mathrm{S}} / \mathrm{L}_{0}$ trench, with different trench depth $\mathrm{H}_{\mathrm{T}}$ and the relative distance from the trench to the foundation is $\mathrm{L}_{0} / \mathrm{H}_{\mathrm{T}}$, where $\mathrm{L}_{\mathrm{S}}$ is the distance between the screen and the trench, $\mathrm{L}_{0}$ is the distance between the foundation of the building and the trench, and $\mathrm{H}_{\mathrm{T}}$ is the depth of the trench.

a)

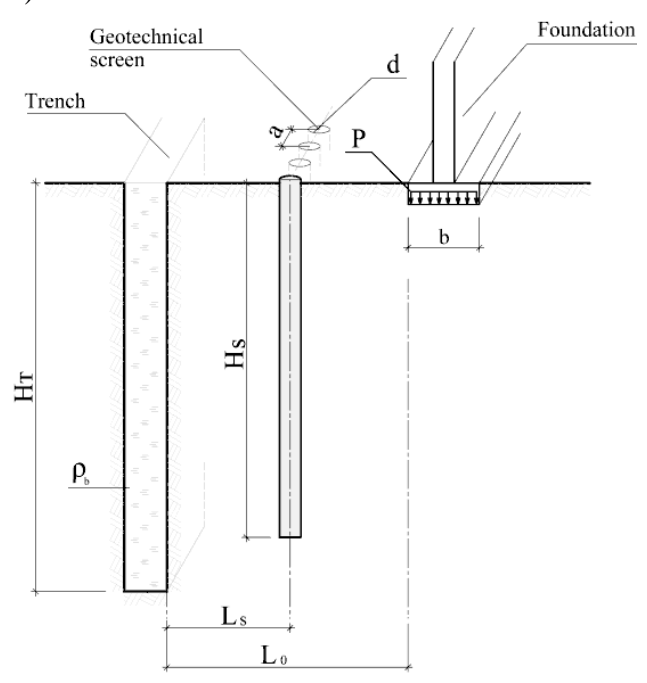

b)

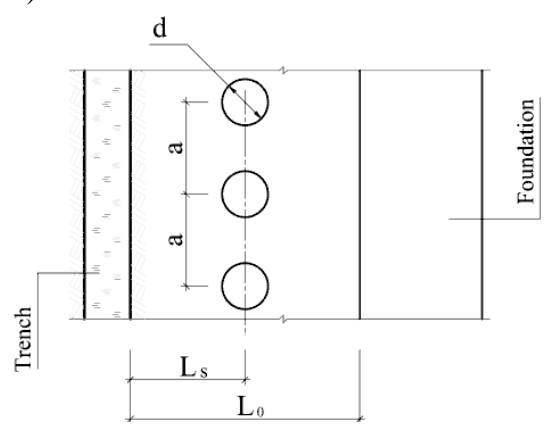

Fig. 5. Development of a trench with a protective screen $\mathrm{a}$ - general view; $\mathrm{b}$ - plane view

The indicated parameters of the pile construction were changed within the following limits:

- diameter of piles d - $200-600 \mathrm{~mm}$;

- relative distance $\mathrm{a} / \mathrm{d}-1$ - 4 ;

- the depth of the screen Hs - $16-36$ m;

- the relative distance from the screen to the trench $\mathrm{Ls}_{\mathrm{L}} / \mathrm{L}_{0}$ is $0,25-0,75$;

- The depth of the trench $\mathrm{HT}_{\mathrm{T}}-20$ - $30 \mathrm{~m}$;

- relative distance from the trench to the foundation $\mathrm{L}_{0} / \mathrm{H}_{\mathrm{T}}-5-10$. 

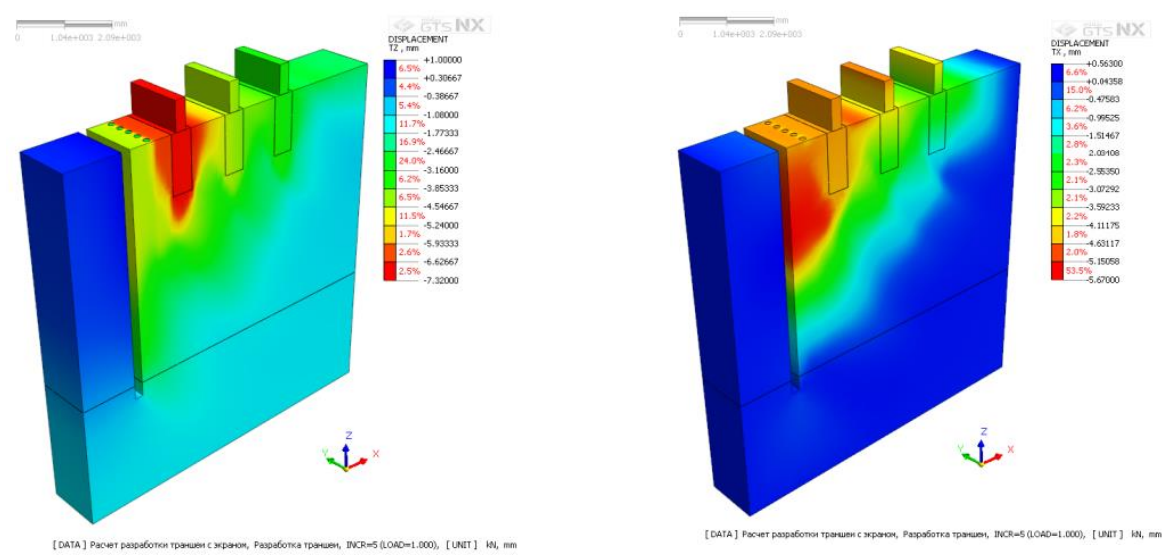

Fig. 6. The calculation results in the development of a trench in the presence of protective screen: $\mathrm{a}$ - strain along the $\mathrm{Z}$ axis; $\mathrm{b}$ - strain along the $\mathrm{X}$ axis

The characteristic deformations obtained by calculation in the vertical and horizontal directions are shown in Fig. 6.

Comparison of the results of the calculations with the results obtained when calculating the effect of developing a trench under the "diaphragm wall" without a protective screen showed that the use of a screen from a sparse row of piles leads to a decrease in settlement of the protected building caused by the device "diaphragm wall".

\section{Results}

Analysis of the calculation results showed the following:

- the settlement analysis of the building caused by digging a trench under the "diaphragm wall" increases with increasing relative distance between piles a/d (Fig. 7) and decreases with increasing diameter of piles (Fig. 8) and the depth of the protective screen (Fig. 9)

- the greatest decrease in precipitation of the protected building is observed when the screen is installed to a depth exceeding by 1-2 $\mathrm{m}$ the depth of the trench under the "diaphragm wall", a further increase in the depth of the screen relative to the bottom of the trench does not practically affect its protective properties;

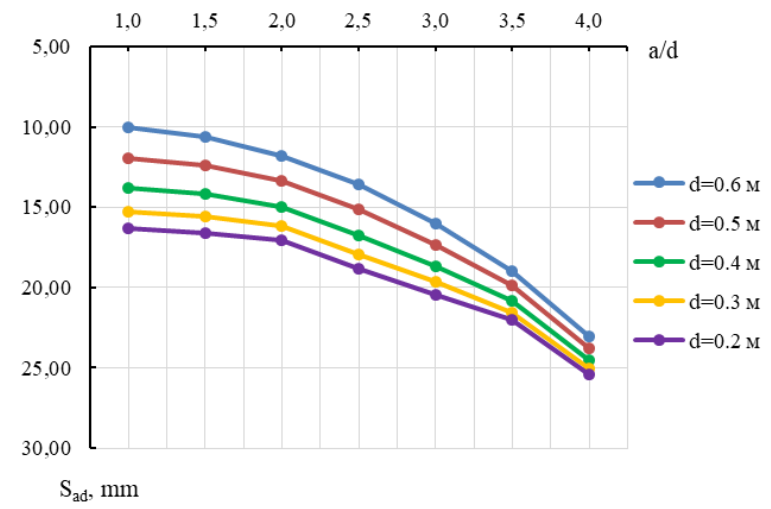

Fig. 7. Dependency graph of additional sediment versus relative distance between screen piles: $S_{a d}=f(a / d)$ with $\mathrm{H}_{\mathrm{S}} / \mathrm{H}_{\mathrm{T}}=1.0 ; \mathrm{L}_{\mathrm{S}} / \mathrm{L}_{0}=0.35$ 


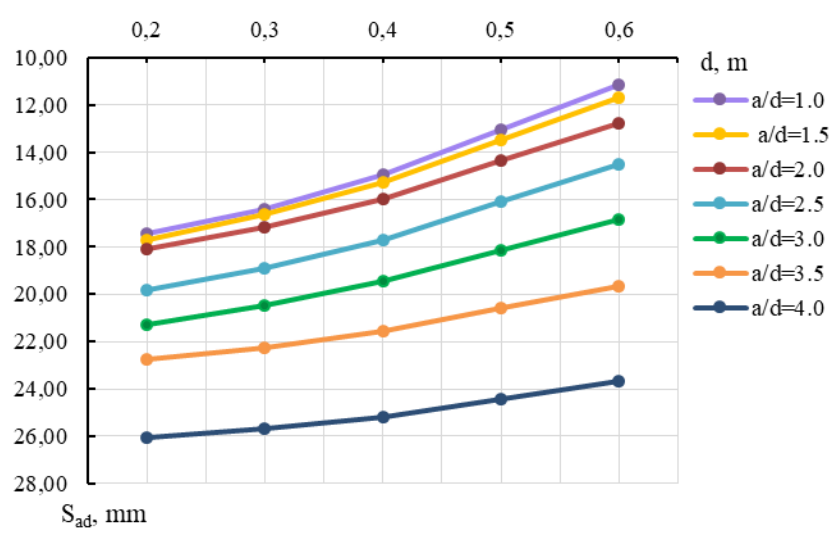

Fig. 8. Dependency graph of additional sediment versus screen diameter $S_{a d}=f(d)$ with $\mathrm{H}_{\mathrm{S}} / \mathrm{H}_{\mathrm{T}}=1.0 ; \mathrm{L}_{\mathrm{S}} / \mathrm{L}_{0}=0.50$

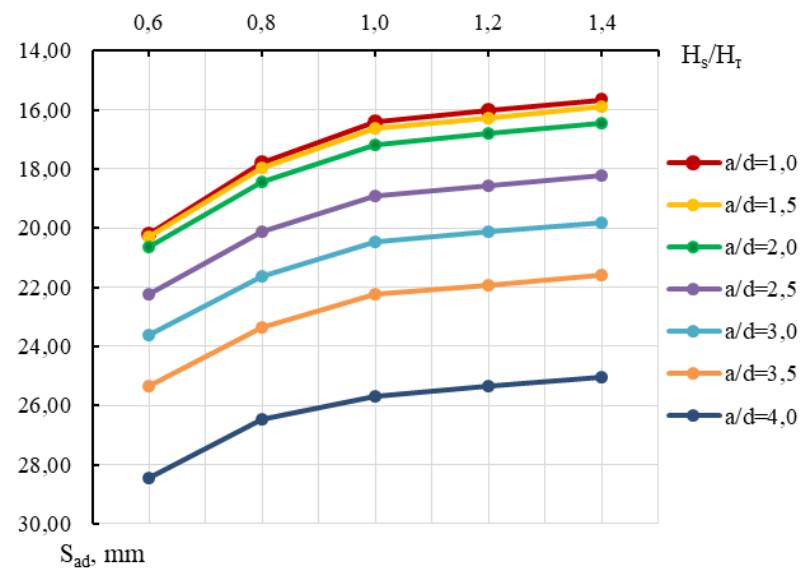

Fig. 9. Dependence graph of additional settlement on the relative screen depth

$$
S_{a d}=f\left(H_{S} / H_{T}\right) \text { with } \mathrm{d}=0.3 \mathrm{~m} ; \mathrm{L}_{S} / \mathrm{L}_{0}=0.50
$$

- the settlement of a building caused by digging up a trench under the "diaphragm wall" decreases as the screen moves away from the protected building, as can be seen from the graphs in Pic. 10.

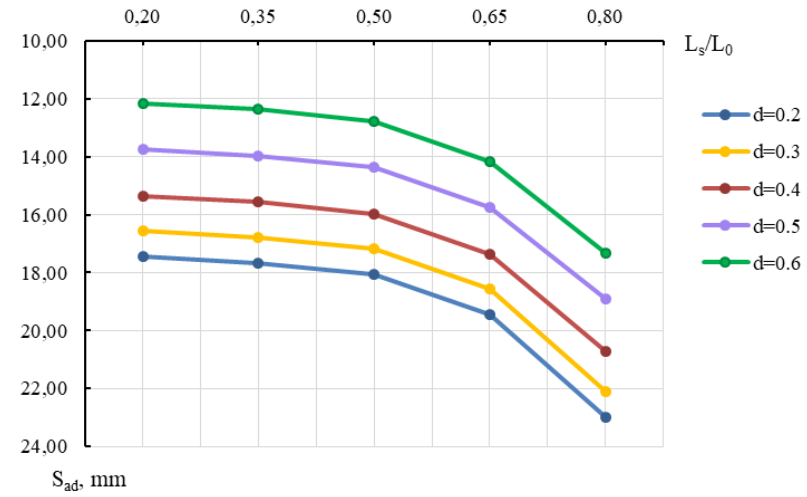

Fig. 10. Dependence graph of additional settlement versus relative screen distance $S_{a d}=f\left(L_{S} / L_{0}\right)$ with $\mathrm{H}_{\mathrm{S}} / \mathrm{H}_{\mathrm{T}}=1.0 ; \mathrm{a} / \mathrm{d}=2.0$ 
The trench depth and its distance from the building foundation have a significant influence on the amount of precipitation. Analysis of the dependence graphs of the building's settlement on the trench parameters and its location (Fig. 11, 12) showed that the precipitation caused by the "diaphragm wall" device with a protective screen increases with increasing trench depth and decreasing its distance to the foundation. At the same time, there is a significant decrease in the intensity of precipitation change when the trench is removed from the basement by more than $5 \mathrm{~m}$. Similar results were obtained for the other considered parameters of the pile structure from a sparse row of piles.

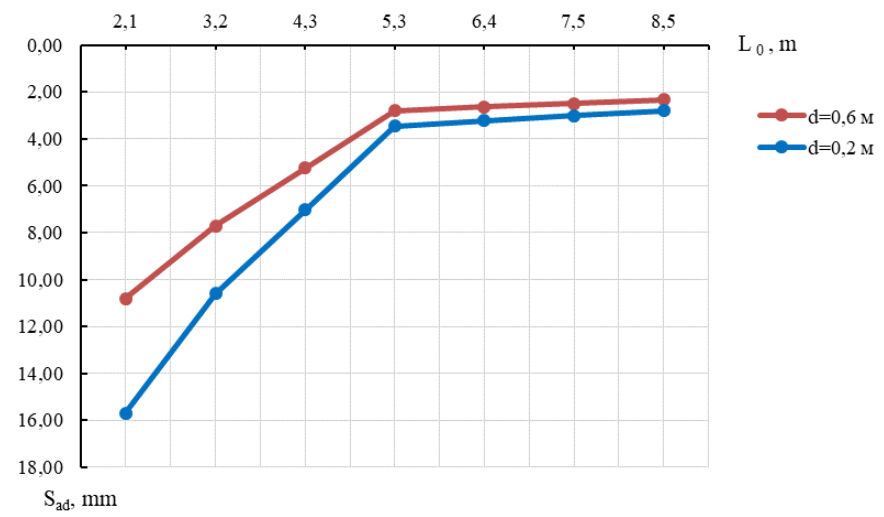

Fig.11. Dependence graph of additional precipitation on the distance between the trench and the foundation $S_{a d}=f\left(/ L_{0}\right)$ with $\mathrm{L}_{S} / \mathrm{L}_{0}=0.25 ; \mathrm{H}_{\mathrm{S}} / \mathrm{H}_{\mathrm{T}}=1.0 ; \mathrm{a} / \mathrm{d}=2.0$

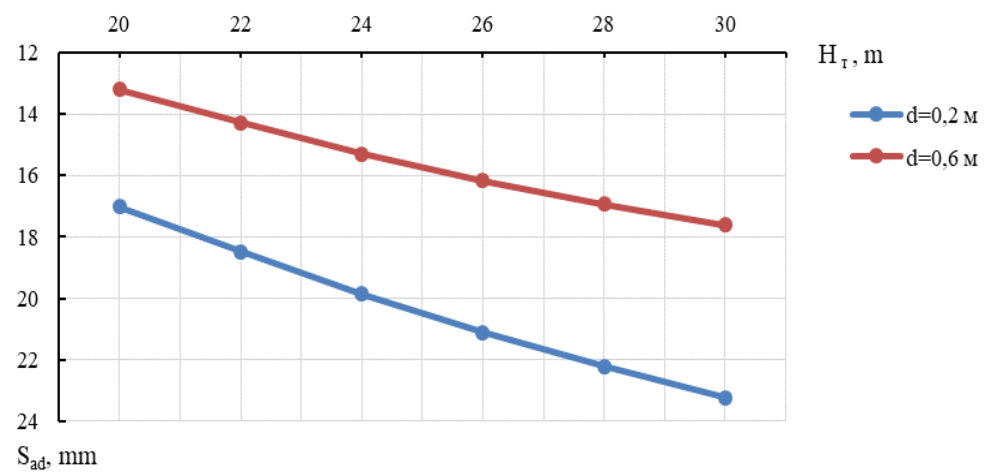

Fig. 12 Dependence graph of additional settlement of the building versus trench depth $S_{a d}=f\left(H_{T}\right)$ with $\mathrm{L}_{0}=2.4 \mathrm{~m} ; \mathrm{L}_{\mathrm{S}} / \mathrm{L}_{0}=0.25 ; \mathrm{H}_{\mathrm{S}}=20 \mathrm{~m} ; \mathrm{a} / \mathrm{d}=2.0$

\section{Conclusion}

1. Analysis made by a numerical method showed that the installation of a geotechnical screen from a sparse row of piles reduces the predicted settlement of the protected building by approximately $30-75 \%$ and is an effective method for reducing the settlement of buildings surrounding the buildings caused by digging up a trench for a monolithic reinforced concrete diaphragm wall, serving as a fence for a building being erected on a nearby construction site.

2. Additional settlement of the building located next to the building's trenches under development, from the parameters of the geotechnical screen increases with 
increasing relative distance between piles a / d, decreases with increasing diameter of piles and the depth of their immersion into the ground.

3. The amount of additional precipitation of a building decreases as the screen moves away from the protected building.

4. Additional settlement of the building, caused by the device "diaphragm wall" with a geotechnical screen, increases with increasing trench depth and decreasing its distance to the foundation of the protected building.

5. The greatest decrease in precipitation of the protected building is observed when the screen is installed to a depth of 1-2 meters above the depth of the trench under the "diaphragm wall", a further increase in the depth of the screen relative to the bottom of the trench does not practically affect its protective properties.

\section{References}

1. D.A. Sapin, Zhilishhnoe stroitelstvo. Osadki fundamentov zdanij sosednej zastrojki pri ustrojstve transhejnoj «steny v grunte», 4, 8 (2015)

2. V.A. Ilichev, V.V. Znamenskiy, E.B. Morozov, D.Yu. Chunyuk, Sb. trudov nauchn. texn. konf. "Aktualnye voprosy geotexniki pri reshenii slozhnyx zadach novogo stroitelstva i rekonstrukcii, Spb., Opyt ustrojstva kotlovanov v gorode Mockve, 33, (2010)

3. V.V. Znamenskiy, D.Yu. Chunyuk, E.B. Morozov, Zhilishhnoe stroitelstvo, Ustrojstvo ograzhdayushhix sistem kotlovanov v stesnenny`x gorodskix usloviyax, 9, 60 (2012)

4. Ch. Moormann, Proc. the XIIIth European conf. on soil mechanics and geotechnical engineering. «Geotechnical problems with man-made and man influenced grounds». Main Session 4: Foundation in urban areas. - Prague, Czech Republic, 25-28th August 2003, Actual trends in deep excavation technology and performance based on an international database, 2, 277 (2003)

5. B.H. Bin-Chen, F.T. David, C. Chun-Hung, N.H. Richard, Hwang, Proc. The 3rd Int. Symp. (IS-Toulouse. 2002) "Geotechnical Aspects of Underground Construction in Soft Ground", 4th Session Deep Excavation: Design and analysis. - Toulouse, Franse, 23-25 October, 2002, The use of piling and propping for the protection of buildings beside deep excavations: case studies from Taipei, Taiwan, 57 (2002)

6. N.S. Nikiforova, D.A. Vnukov, The proc. of the 7th Int. Symp. "Geotechnical aspects of underground construction in soft ground”, 16-18 May, 2011, tc28 IS Roma, AGI, 2011, No157NIK, Geotechnical cut-off diaphragms for built-up area protection in urban underground development, 15 (2011)

7. A.A. Starshinov, A.A. Fursov, A.D. Kuznecov, Geotekhnika. Ocenka sostoyaniya osnovanii sooruzhenii: sb. tr. mezhd. konf. 13-16 iyunya 2001. - SPb, 2001. - T. II Opyt razrabotki sistemy monitoringa na osnove prognoza vliyaniya podzemnogo stroitelstva na okruzhayushchuyu zastroiku v usloviyah g. Moskvy, II, 191 (2001) 